\title{
CASE OF ADDISON'S DISEASE.
}

[Reported to the Boston Society for Medical Improvement, and communicated for the Boston Medical and Surgical Journal.]

By CaLvin ELLIS, M.D.

The patient was a gentleman, 37 years of age, and belonged to a healthy family. In 1843 he had a severe attack of typhoid fever, from which he very slowly recovered. With this exception, he had always enjoyed good health. His labors as a lawyer during the last two years of his life were at times excessive. In the winter of 1860 and spring of 1861 , he complained more of fatigue than usunl, but this was attributed to his close application to business. The debility slowly increased, the countenance became sallow, and he lost some flesh, but continued to attend to his business as usual, until about the middle of October, when he visited Washington, but excrtion caused so much fatigue that the journey afforded him no pleasure. On his return, he was attacked, in Philadelphia, with symptoms like those which indicate the approach of typhoid fevor. He reached home on the 28 th of October. The mind was perfectly clear, and but little complaint was then or afterwards made of anything except debility, and at times restlessuess or slecplessness. There was occasionally a little fever. The pulse varied from 90 to 100 . The bowels were generally costive, but grcat care was necessary in the administration of aperients, as faintness followed almost every discharge. The dejections were thin, and of a yellow color, like those of typhoid fever. Although the latter was not clcarly indicated by tho symptoms, and there was some doubt for a number of days, the appearance of an eruption on the abdomen, like that usually seen, seemed to make the diagnosis clcar. The persistence of this, however, for some weeks, and the subsequent changes, make it probable that no such discase ever existed.

The prostration being marked, the treatment was of a tonic character and the diet nutritious, such articles of food being selected as were most casily digested. The appetite was deficient, and nausea was at times complained of. In the course of a month he began to improve a little, but never showed that disposition to rise, and the strong appetite, which so often indicate recovery from disease. Instead of wishing to do more than was safe, it was necessary to urge him to make any exertion. He very slowly gained, however, so that on Noromber 17 th he rode out, and continued to do so until the middle of December, when he returned to his office and spent several hours there daily for a short time; ho then felt decidedly worse and confined himself mostly to the house, unless he rode out, which he frequently did. On Feb. 15th, he rode twenty miles in a close carriage, but was much fatigued on his return, and soon after was again confined to his bed. During all this time he gained no flesh, had but little appetite, and complain- 
ed constantly of great fatigue and dyspncea upon the slightest exertion. Upon one occasion he fainted soon after leaving the house in a carriage.

Repeated examinations of all the organs and functions failed to show any cause for the persistence of these alarming symptoms. The countenance had never lost the dark, sallow hue noticed carly in the illness, and about the middle of March there was seen a decided dark-brown discoloration of the folds of the skin of the neck. The same was secn behind the ears, upon the shoulders and knees, but less marked. It was then ascertained that the change had existed for some time. An accurate cxamination could not be made, as it was necessary to divert the patient's mind firom the subject. Tho worst fears werc now expressed, but in a few days he began to improve. He had constantly complained of slight nausca, but the appetite now became quite strong, and his daily meals assumed great importance. Tho strength also improved, so that he went to the dinner table, saw his friends in the parlor, and rode out several times. This continued until a week before his death, but he did not gain flesh, and the discoloration of the skin never diminished. The strength and appetite again declined, but his condition was no more alarming than it had been months before, until the last two days, when nausca, debility and restlessness became very troublesome. Without any other marked change, he died on May 5th.

With the peculiar discoloration of the skin, the most striking symptoms wore great debility and dyspnœa, the latter being, howover, only another expression of the former, and never indicating any pulmonary disease. The mind was always clcar, the pulse but slightly accelcrated-though always very feeble, and there was very littlo fever. With these there was an entire absence of symptoms which indicated diseasc of any organ to which the attention of the physician is usually called.

At the post-mortcm examination, the supra-renal capsules were found to be of twice or thrice the natural size, dense and disorganized, the tissue somewhat rescmbling tubcrcle. In some portions of the tissue was found fluid resembling recent pus. No other recent disease was found in the body. The discoloration of the skin was well-marked.

\section{Armp Axerical Antelligence.}

To the Surgeon-General.

Nrwhirs, N. C., Mny 12th, 1863.

Sik,-Knowing your desire to be kept informed of the condition of the Massachusetts troops, I take the liberty to write you now concerning the regiment under my charge.

At present we are engaged in taking down and rebuilding our barracks. Strangely enough, these were built directly in front of Fort 